\title{
Water Intrusion in the Chesapeake Bay Region: Is It Caused by Climate-Induced Sea Level Rise?
}

\author{
Roger H. Bezdek \\ Management Information Services, Inc., Washington, D.C., USA \\ Email: bezdek@misi-net.com
}

How to cite this paper: Bezdek, R.H. (2017) Water Intrusion in the Chesapeake Bay Region: Is It Caused by Climate-Induced Sea Level Rise? Journal of Geoscience and Environment Protection, 5, 252-263. https://doi.org/10.4236/gep.2017.58020

Received: March 21, 2017

Accepted: August 19, 2017

Published: August 22, 2017

Copyright (C) 2017 by author and Scientific Research Publishing Inc. This work is licensed under the Creative Commons Attribution International License (CC BY 4.0).

http://creativecommons.org/licenses/by/4.0/ (c) (i) Open Access

\begin{abstract}
Sea level rise due to climate change is a contentious issue with profound geographic and economic implications. One region in the USA identified as being particularly susceptible to seal level rise is the Chesapeake Bay region, and it has been estimated that by the end of the century Norfolk, Virginia could experience sea level rise of 0.75 meters to more than 2.1 meters. Water intrusion is a serious problem in much of the Chesapeake Bay region. The question addressed here is whether this water intrusion is the result of climate-induced seal level rise or is being caused by other factors. Our findings indicate that the water intrusion problems in the region are due not to "sea level rise", but primarily to land subsidence due to groundwater depletion and, to a lesser extent, subsidence from glacial isostatic adjustment. We conclude that water intrusion will thus continue even if sea levels decline. These findings are critical because the water intrusion problems in the Chesapeake Bay-and elsewhere-cannot be successfully solved unless their causes are correctly identified and appropriate remedies are devised. For the Chesapeake Bay region, the required remedy is the reversal of groundwater withdrawal rates, which has been used successfully elsewhere in the USA and other nations to solve water intrusion problems.
\end{abstract}

\section{Keywords}

Sea Level Rise, Climate Change, Global Warming, Water Intrusion, Chesapeake Bay, Climate Change Mitigation

\section{Introduction}

Numerous studies contend that there are serious dangers and risks to many U.S. regions from anthropogenic global warming (AGW), and the Southeast region is identified as likely to be impacted the most severely. For example, recent reports 
warned that sea level rise seriously threatens the Southeast's coastal infrastructure, and contended that there was a significant risk to this region from sea level rise [1]. Thus, "On our current path, by mid-century, mean sea level at Norfolk, Virginia-home to the USA's largest naval base-will likely rise between 0.33 meters and 0.52 meters, and will rise 0.75 meters to 1.34 meters by the end of century. However, there is a 1-in-100 chance that Norfolk could see sea level rise of more than 2.2 meters by the end of the century." [2] This is illustrated in Figure 1 . However, these were projected values with a large range of uncertainties and depended strongly on what climate-model outputs were employed for the projection. Here we examine this issue in detail, and we assess whether the water intrusion problems in the Norfolk, Virginia region are the result of AGW-induced seal level rise or are being caused by other factors.

\section{Land Subsidence and Relative Sea-Level Rise}

Land subsidence is the sinking or lowering of the land surface, and most land subsidence in the U.S. is caused by human activities [3]. Two well-studied cases of land subsidence are in the Houston-Galveston, Texas, area and the Santa Clara Valley, California. Land sank by as much as three meters over 50 years because of intensive groundwater withdrawals in the two areas, as well as petroleum extraction in Texas, resulting in increased coastal flooding [4]. Regional authorities were established in the two areas to manage water use and land subsidence. The regional authorities set up monitoring networks and enlisted scientists to study

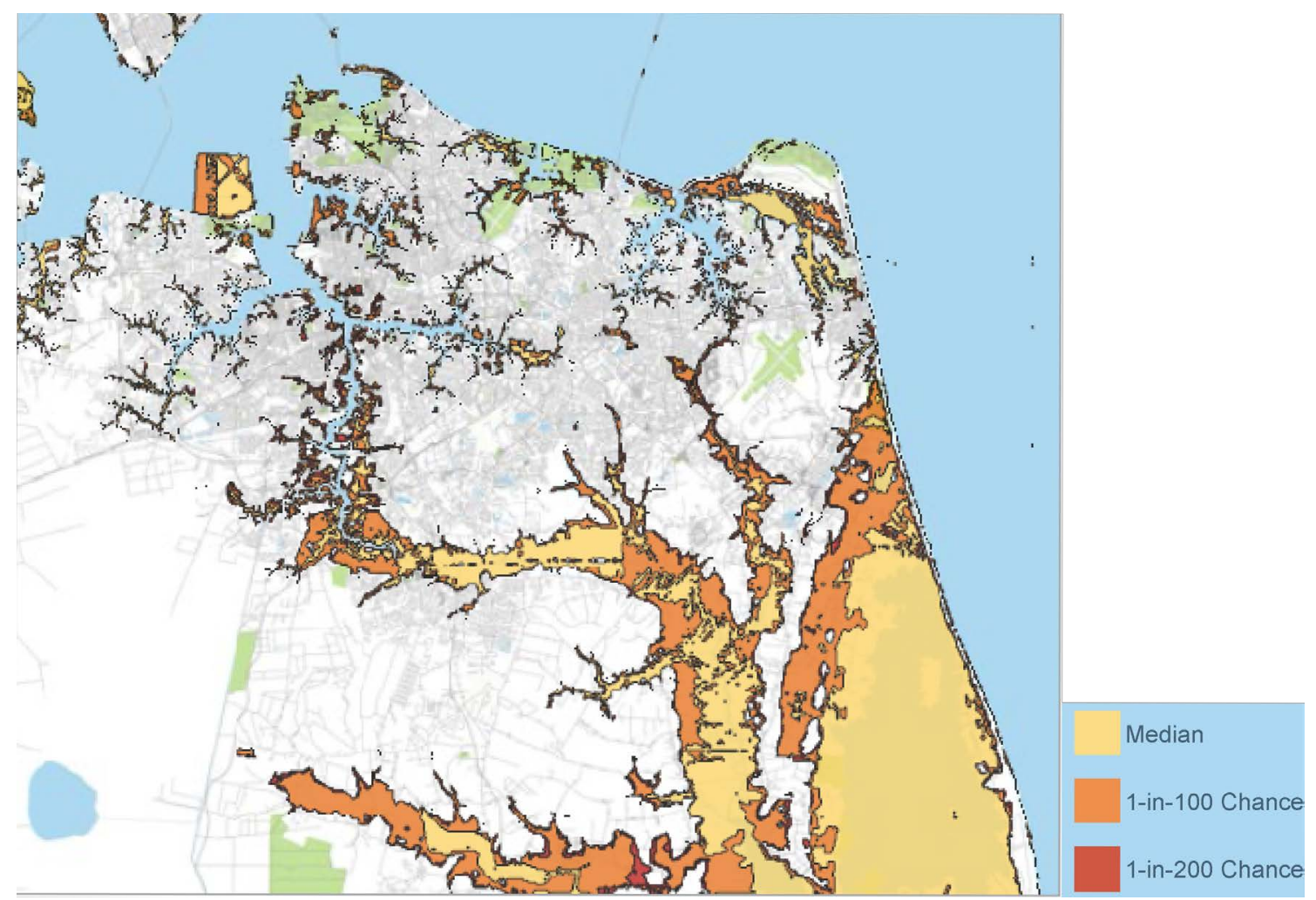

Figure 1. Mean sea level rise in Norfolk by 2100. (Source: Risky Business.) 
the problem Ultimately, the communities adopted new water-management practices to prevent land subsidence, including relocating groundwater withdrawals away from the coast, substituting surface water [5] for groundwater supplies, and increasing aquifer recharge. In the Santa Clara Valley, subsidence has mostly been stopped and, in the Houston-Galveston area, subsidence has been slowed, particularly along vulnerable shorelines [3].

Rates and locations of land subsidence change over time, so accurate measurements and predictive tools are needed to improve understanding of land subsidence. Although rates of land subsidence are not as high on the Atlantic Coast as they have been in the Houston-Galveston area or the Santa Clara Valley, land subsidence is important because of the low-lying topography and susceptibility to sea-level rise in the southern Chesapeake Bay region.

Land subsidence can increase flooding, alter wetland and coastal ecosystems, and damage infrastructure and historical sites. Because land subsidence contributes to relative sea-level rise in the region, it is important to understand why, where, and how fast it is occurring, now and in the future.

Land subsidence is causing most of the relative "sea-level rise" that has been measured in the Chesapeake Bay. However, tidal-station measurements of sea levels do not distinguish between water that is rising and land that is sinkingthe combined elevation changes are termed "relative sea-level rise". Land subsidence is the sinking or lowering of the land surface and it increases the risk of coastal flooding and contributes to water intrusion and shoreline retreat-Figure 2.

As relative sea levels rise, shorelines retreat and the magnitude and frequency of near-shore coastal flooding increase. Although land subsidence can be slow, its effects accumulate over time. This has been an expensive problem in the Houston-Galveston area and the Santa Clara Valley [5] and contributes to current flooding problems in the Chesapeake Bay region. Analysts found that between 59,000 and 176,000 residents living near the shores of the Chesapeake Bay could be either permanently inundated or regularly flooded by 2100 [6]. Damage to personal property was estimated to be $\$ 9$ billion to $\$ 26$ billion, and 120,000 acres of ecologically valuable land could be inundated or regularly flooded, under these same assumptions. However, the key question is whether AGW-induced sea level rise is the causal factor.

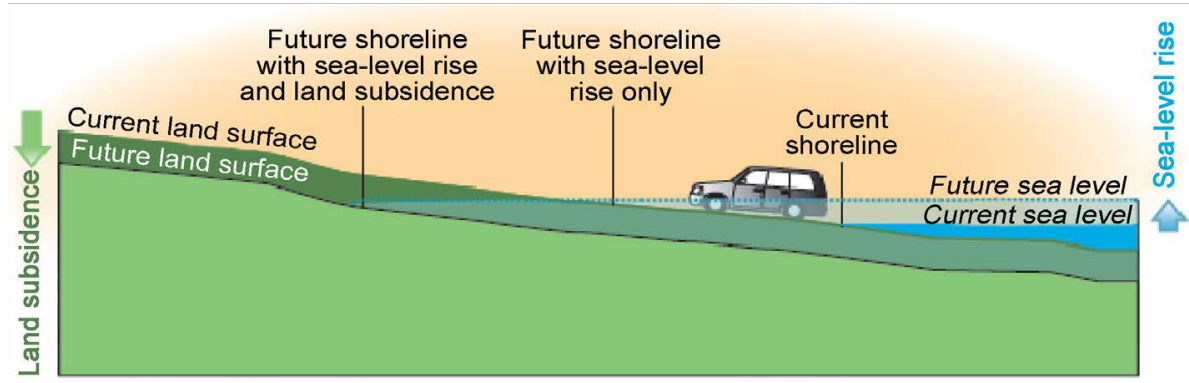

Figure 2. Shoreline retreat caused by a combination of sea-level rise and land subsidence. (Source: USGS.) 
Land subsidence can also increase flooding in areas away from the coast. Low-lying areas, such as the Blackwater River Basin in Virginia can be subject to increased flooding as the land sinks. Locations along the Blackwater River in the city of Franklin and the counties of Isle of Wight and Southampton have experienced large floods in recent years [3]. Land subsidence may be altering the topographic gradient that drives the flow of the river and contributing to the flooding.

\section{Causes of Land Subsidence in the Chesapeake Bay Region}

It is important to understand the causes of land subsidence so that it can be more effectively managed. Most land subsidence in the U.S. is caused by human activities, with groundwater withdrawals responsible for about 80 percent of land subsidence in the U.S. [7]. Causes of subsidence that are most relevant to the Chesapeake Bay region include aquifer-system compaction caused by groundwater withdrawals and glacial isostatic adjustment.

When groundwater is pumped from an aquifer system, pressure decreases. The pressure change is reflected by water levels in wells, with water levels decreasing as aquifer-system pressure decreases. This is happening over most of the Chesapeake Bay region, with the greatest water-level decreases seen near the pumping centers of Franklin and West Point, Virginia-Figure 3. As water levels decrease, the aquifer system compacts, causing the land surface above to subside. Water levels have decreased over the entire Virginia Coastal Plain in the Potomac aquifer, which is the deepest and thickest aquifer in the southern Chesapeake Bay region and supplies about 75 percent of groundwater withdrawn from the Virginia Coastal Plain aquifer system [8].

The amount of aquifer-system compaction is determined by three factors: Water-level decline, sediment compressibility, and sediment thickness. If any of these three factors increase in magnitude, then the amount of aquifer-system compaction and land subsidence increases. Because all three of these factors vary spatially across the southern Chesapeake Bay region, rates of land subsidence caused by aquifer-system compaction also vary spatially across the region.

The Virginia Coastal Plain aquifer system consists of many stacked layers of sand and clay. Although groundwater is withdrawn primarily from the aquifers (sandy layers), most compaction occurs in confining units and clay lenses, the relatively impermeable layers sandwiched between and within the aquifers [9]. The compression of clay layers is mostly non-recoverable, meaning that, if groundwater levels later recover and increase, then the aquifer system does not expand to its previous volume and the land surface does not rise to its previous elevations [7]. It has been estimated that 95 percent of the water removed from storage in the Virginia Coastal Plain aquifer system between 1891 and 1980 was derived from the confining layers [10].

The timing of aquifer-system compaction is also important. Compaction can continue for many years or decades after groundwater levels decline. When groundwater is pumped from an aquifer, pressure decreases in the aquifer. The 


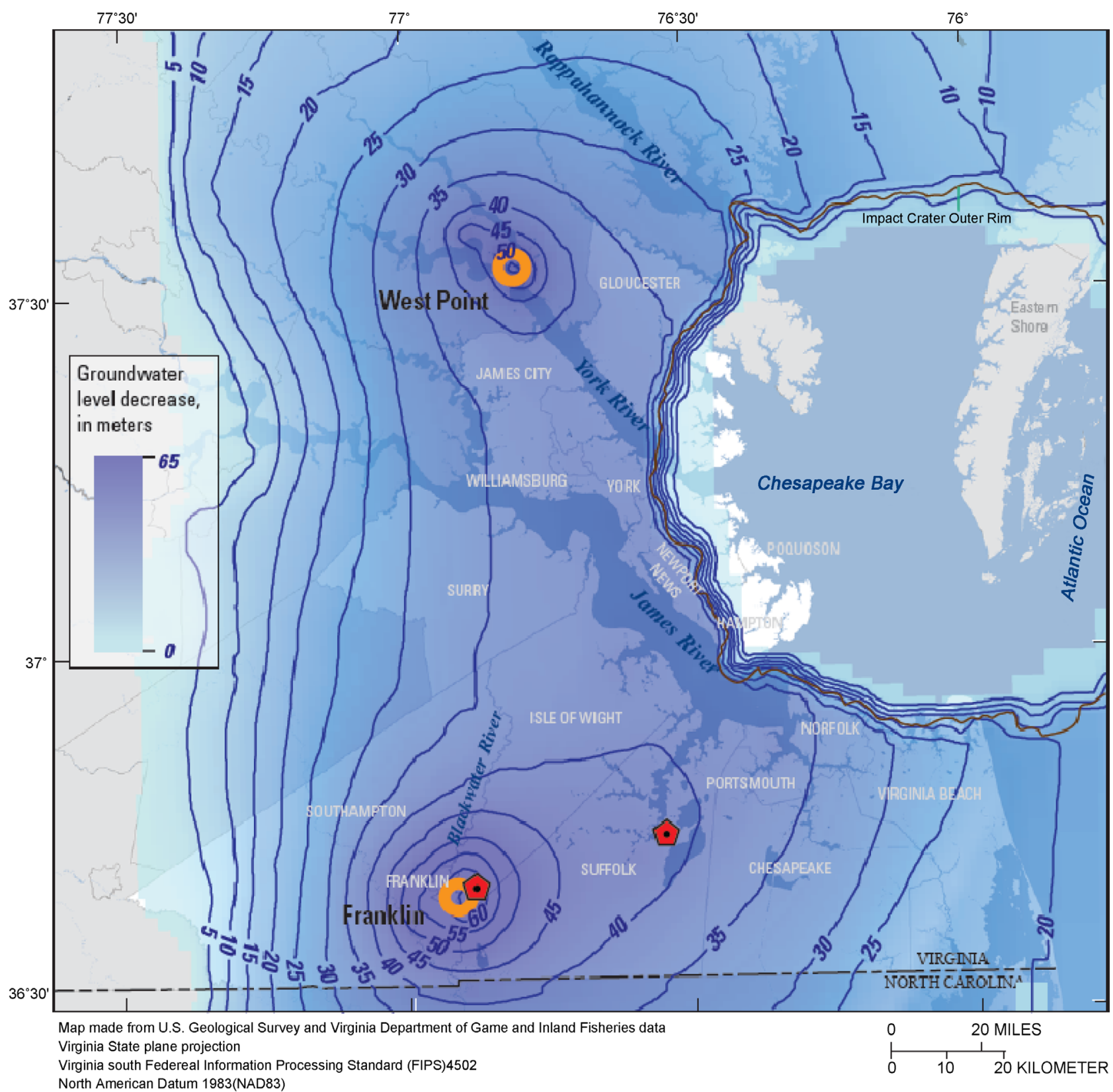

EXPLANATION

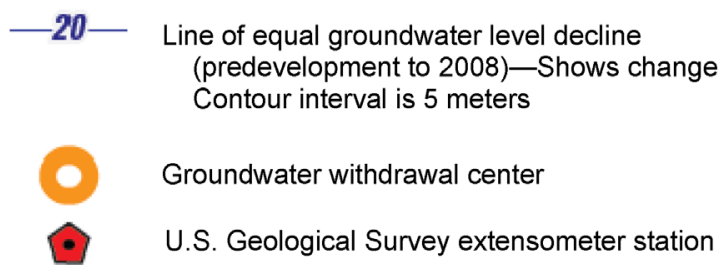

Figure 3. Chesapeake Bay groundwater water-level decreases, 1900 to 2008. (Source: USGS.)

pressure decrease then slowly propagates into clay layers that are adjacent to or within the aquifer, and as long as pressure continues to decrease in the clay layers, compaction continues. 
The layered sediments of the Virginia Coastal Plain aquifer system range in grain size from very fine (silts and clays) to coarse (sand and shell fragments) [10]. Confining layers outside the meteor impact crater occupy about 16 percent of the total aquifer-system thickness, an average of $100 \mathrm{~m}$ out of the total average thickness of $619 \mathrm{~m}$ [8]. Clay layers overlying and within the Potomac aquifer are compressing as aquifer pressure decreases migrate vertically and laterally from pumping wells [11].

Crystalline bedrock underlies the layered sediments of the Virginia Coastal Plain aquifer system, but the bedrock is not solid and unyielding but actually flexes and moves in response to stress. Bedrock in the mid-Atlantic region is moving slowly downward in response to melting of the Laurentide ice sheet that covered Canada and the northern U.S. during the last ice age [12]. When the ice sheet still existed, the weight of the ice pushed the underlying Earth's crust downward and, in response, areas away from the ice sheet were forced upward (called glacial forebulge). The southern Chesapeake Bay region is in the glacial forebulge area and was forced upward by the Laurentide ice sheet. The ice sheet started melting about 18,000 years ago and took many thousands of years to disappear entirely. As the ice melted and its weight was removed, glacial forebulge areas, which previously had been forced upward, began sinking and continue to sink. This movement of the Earth's crust in response to ice loading or melting is called glacial isostatic adjustment. Data from GPS measurements and carbon dating of marsh sediments indicate that regional land subsidence in response to glacial isostatic adjustment in the Chesapeake Bay region may have a current rate of about $1 \mathrm{~mm} / \mathrm{yr}$ [13].

There are other causes of land subsidence, but there is currently little or no evidence that these other causes are important to regional subsidence processes in the southern Chesapeake Bay region. These include bedrock dissolution, drainage and degradation of organic soils, settling of fill and disturbed soils [14], and volcanic disturbances and tectonic motion related to continental crust movements. Settling of impact crater sediments associated with the Chesapeake Bay meteor crater is an unlikely cause of current land subsidence in the region because the meteor struck about 35 million years ago [15]. The passage of time since the meteor impact has been so great that, even if it was conservatively assumed that subsidence rates had stayed constant during the past 1 million years rather than decreasing, a rate of $1 \mathrm{~mm} / \mathrm{yr}$. would equate to 1 kilometer of subsidence, which is not compatible with current understanding of regional geology [16].

\section{Land Subsidence and Sea-Level Rise in the Chesapeake Bay Region}

Land subsidence has been known and observed in the southern Chesapeake Bay region for many decades and is a factor that must be considered by urban planners and natural resource managers. Land subsidence in the Chesapeake Bay re- 
gion was first documented over four decades ago by Holdahl and Morrison who reported results of geodetic surveys completed between 1940 and 1971 and found land surfaces across the region were sinking at an average rate of 2.8 $\mathrm{mm} / \mathrm{yr}$. with rates ranging from 1.1 to $4.8 \mathrm{~mm} / \mathrm{yr}$ [17]. The two areas where subsidence rates were the most rapid roughly coincide with groundwater pumping centers at Franklin and West Point. Measurements of land subsidence are currently made at Continuously Operating Reference Stations (CORS) in the region. The National Geodetic Survey has computed velocities for three of these stations between 2006 and 2011 and found an average subsidence rate of 3.1 $\mathrm{mm} / \mathrm{yr}[18]$.

Aquifer-system compaction was measured with extensometers at two locations in the region, at Franklin from 1979 to 1995 and at Suffolk from 1982 to 1995 [19]. The extensometers showed $24.2 \mathrm{~mm}$ of total compaction at Franklin from 1979 through 1995 ( $1.5 \mathrm{~mm} / \mathrm{yr}$.) and $50.2 \mathrm{~mm}$ of total compaction at Suffolk from 1982 through 1995 (3.7 mm/yr.). Rates of compaction were correlated to groundwater-level decreases and to the aggregate thickness of compressible sediments at each location. The total thickness of compressible fine-grained sediments is $130.8 \mathrm{~m}$ at Suffolk and $62.7 \mathrm{~m}$ at Franklin. Water levels in the Potomac aquifer during the period of compaction measurement decreased more at Suffolk than at Franklin, about $5 \mathrm{~m}$ versus about $2 \mathrm{~m}$. Aquifer-system compaction has not been measured at any other locations in the Chesapeake Bay region but it likely affects most of the region because large water-level decreases in the aquifer system are widespread.

Relative sea-level rise measured at four National Oceanic and Atmospheric Administration (NOAA) tidal stations averaged $3.9 \mathrm{~mm} / \mathrm{yr}$. from about 1950 through 2006. At the Sewells Point tidal station in Norfolk, Virginia, rising sea levels have been recorded since 1927: Sea level at Sewells Point rose at an average rate of $4.4 \mathrm{~mm} / \mathrm{yr}$. from 1927 to 2006, with a 95 percent confidence interval of \pm 0.27 $\mathrm{mm} / \mathrm{yr}$ [20]. In comparison, global average sea levels have been rising at about $1.8 \mathrm{~mm} / \mathrm{yr}$. Although rates of absolute sea-level rise (rise due just to increases in ocean volume) can vary substantially from one location to another and change over time [21], the global average rate of $1.8 \mathrm{~mm} / \mathrm{yr}$. from 1961 to 2003 is a widely accepted global benchmark rate [22]. The difference between the average sea-level rise computed from the four NOAA tidal stations in the study area (3.9 $\mathrm{mm} / \mathrm{yr}$.) and the benchmark global rate $(1.8 \mathrm{~mm} / \mathrm{yr}$.) is $2.1 \mathrm{~mm} / \mathrm{yr}$., which is an estimate of the average rate of land subsidence at the four NOAA stations.

However, as noted, local regional sea level rise can differ significantly from the global mean sea level rise [23]. Chesapeake Bay tide-gage records and paleo-sea-level records from tidal marshes and the bay's main stem indicate that rates of sea-level rise in Chesapeake Bay range from about 3.2 to $4.7 \mathrm{~mm} / \mathrm{yr}$., depending on the location and period of record for each tide gage. These rates exceed the global average because the land is subsiding. Further, the departure of sea-level trends in Chesapeake Bay from the global mean for the last century may not persist. Thus, rates measured at tide gages do not necessarily reflect 
pre-20th century regional patterns, nor can they be necessarily expected to persist into the future [24]. Nevertheless, the estimates used here are currently the best available and are supported by the research literature [25].

Thus, the difference between average subsidence rate of about $3.1 \mathrm{~mm} / \mathrm{yr}$ and the average estimated sea-level rise computed in the Chesapeake Bay area of about $3.9 \mathrm{~mm} / \mathrm{yr}$. is $0.8 \mathrm{~mm} /$ year. These data indicate that land subsidence has been responsible for most of the relative sea-level rise measured in the Chesapeake Bay region over the past half-century.

\section{Links between Groundwater Withdrawals and Land Subsidence}

Aquifer-system compaction is responsible for most land subsidence in the region, based on average measured land subsidence rates of about $2.8 \mathrm{~mm} / \mathrm{yr}$. and measured average compaction rates of $2.6 \mathrm{~mm} / \mathrm{yr}$. The aquifer-system compaction is caused by high groundwater withdrawal rates that have lowered water levels [26]. As shown in Figure 4, groundwater withdrawal rates in the region increased sharply in the 20th century as modern pumping technology was widely adopted [7]. The many decades of increasing groundwater withdrawals have caused groundwater levels to decrease across the Chesapeake Bay region. Water levels are expected to continue decreasing for many years, even if pumping rates do not increase further, because of delay caused by compressibility of the aquifer system [8].

An important component of relative sea-level rise, land subsidence, could be prevented or reduced in the future if groundwater pumping strategies were changed [27]. Future land subsidence caused by aquifer-system compaction can be

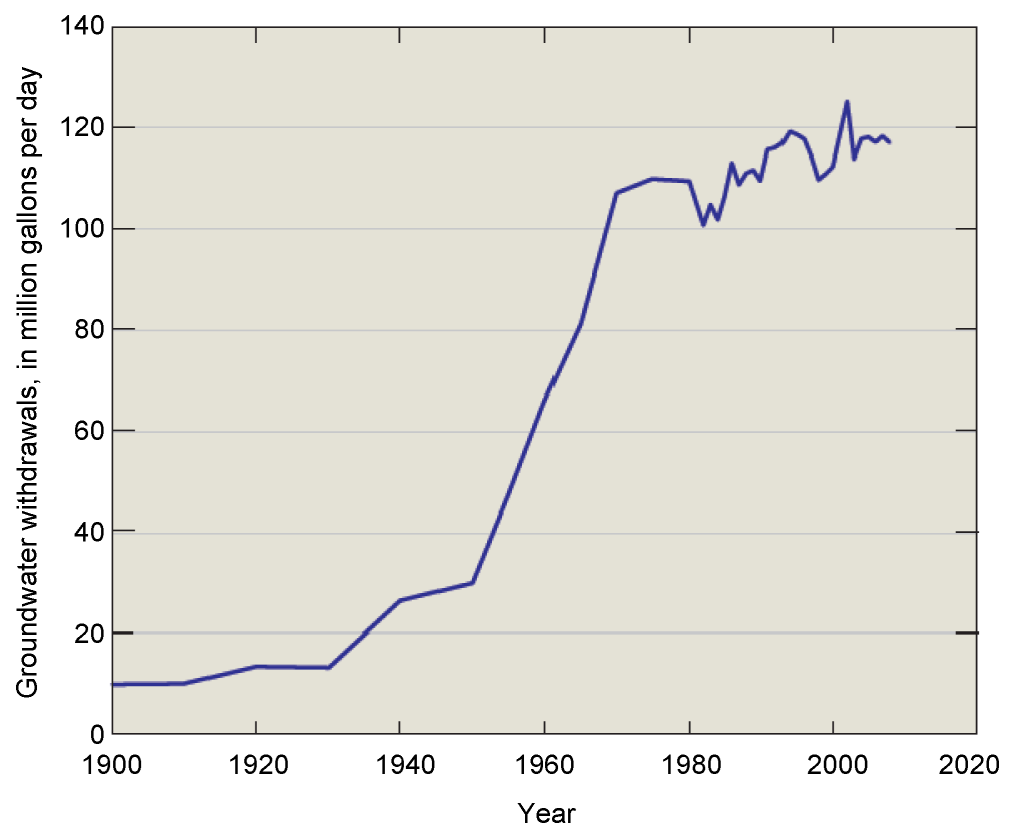

Figure 4. Groundwater withdrawal rates from Virginia coastal plain aquifers, 1900 to 2008. (Source: USGS.) 
reduced or stopped by changing water-use practices. Because aquifer-system compaction is the primary cause of land subsidence in the Chesapeake Bay region, reducing compaction can reduce land subsidence and associated flood risks [28]. In the Houston-Galveston area and the Santa Clara Valley, resource managers have successfully decreased land subsidence by moving groundwater pumping away from the coast, reducing groundwater withdrawal rates, and increasing aquifer recharge [29]. Similar findings have been reported for the San Joaquin Valley, California [30], coastal Louisiana [31], the Yellow River delta, China [32], and the central Ganges-Brahmaputra Delta, Bangladesh [33].

The small contribution to land subsidence from glacial isostatic adjustment in the Chesapeake Bay region-perhaps about $1 \mathrm{~mm} / \mathrm{yr}$ [33] —cannot be prevented. This natural glacial isostatic adjustment of the Earth's crust will diminish with time, but at a glacial or geologic pace.

\section{Conclusions}

Sea level rise due to climate change is a contentious issue with profound geographic and economic implications, and there is little doubt that water intrusion is a serious problem in much of the Chesapeake Bay region. However, the critical question is whether this water intrusion is the result of climate-induced sea level rise or is being caused by other factors. Our findings indicate that the water intrusion problems in the region are due not to "sea level rise", but, rather, primarily to land subsidence due to groundwater depletion and, to a lesser extent, subsidence from glacial isostatic adjustment. We conclude that water intrusion may thus continue even if sea levels actually decline.

The difference is critical, and the solutions required to address the problem are entirely different. If the cause of the problem is primarily land subsidenceas it is in Norfolk and the Chesapeake Bay region, then water intrusion will continue irrespective of sea level changes. For the Chesapeake Bay region, the required remedy is the reversal of groundwater withdrawal rates, which has been used successfully elsewhere in the USA to solve water intrusion problems-including in the Houston-Galveston, Texas area, and the Santa Clara Valley in California. Future land subsidence caused by aquifer-system compaction in the Chesapeake Bay region can be reduced or stopped by changing water-use practices. Our findings are significant because the water intrusion problems in the Chesapeake Bay-or elsewhere-cannot be successfully resolved unless their causes are correctly identified and appropriate remedies are devised.

\section{Acknowledgements}

The author is grateful to Willie Soon, Fred Singer, and several anonymous reviewers for comments on an earlier draft of this manuscript.

\section{References}

[1] Van Houtven, S.G., Depro, B., Lapidus, D., Allpress, J. and Lord, B. (2016) Costs of 
Doing Nothing: Economic Consequences of Not Adapting to Sea Level Rise in the Hampton Roads Region. Report Prepared for the Virginia Coastal Policy Center College of William \& Mary Law School, RTI Project Number 0215176.000.001.

[2] Rhodium Group (2014) Risky Business: The Economic Risks of Climate Change in the United States, Report Prepared for the Risky Business Project. In This Report, Sea-Level Rise Was Measured in Feet. Here We Converted the Measurements to Meters to Be Consistent with Other Estimates.

[3] Galloway, D.L., Jones, D.R. and Ingebritsen, S.E. (1999) Land Subsidence in the United States. U.S. Geological Survey Circular 1182.

[4] Bawden, G.W., Johnson, M.R., Kasmarek, M.C., Brandt, J. and Middleton, C.S. (2012) Investigation of Land Subsidence in the Houston-Galveston Region of Texas by Using the Global Positioning System and Interferometric Synthetic Aperture Radar, 1993-2000. U.S. Geological Survey Scientific Investigations Report 20125211.

[5] McFarlane, B.J. (2012) Climate Change in Hampton Roads. Phase III-Sea Level Rise in Hampton Roads, Virginia. Hampton Roads Planning District Commission Report PEP12-06, Chesapeake.

[6] Federal Emergency Management Agency (2002) Flood Insurance Study of Franklin, Virginia, Community.

[7] Konikow, L.F. and Neuzil, C.E. (2007) A Method to Estimate Groundwater Depletion from Confining Layers. Water Resources Research, 43.

https://doi.org/10.1029/2006WR005597

[8] Pope, J.P. and Burbey, T.J. (2004) Multiple-Aquifer Characterization from Single Borehole Extensometer Records. Ground Water, 42, 45-58. https://doi.org/10.1111/j.1745-6584.2004.tb02449.x

[9] Pope, J.P. (2002) Characterization and Modeling of Land Subsidence Due to Groundwater Withdrawals from the Confined Aquifers of the Virginia Coastal Plain. Virginia Polytechnic Institute, M.S. Thesis.

[10] McFarland, E.R. and Bruce, T.S. (2006) The Virginia Coastal Plain Hydrogeologic Framework. U.S. Geological Survey Professional Paper 1731.

[11] Sella, G.F., Stein, S., Dixon, T.H., Craymer, M., James, T.S., Mazzotti, S. and Dokka, R.K. (2007) Observation of Glacial Isostatic Adjustment in "Stable" North America with GPS. Geophysical Research Letters, 34, L02306.

[12] Engelhart, S.E. and Horton, B.P. (2012) Holocene Sea Level Database for the Atlantic Coast of the United States. Quaternary Science Reviews, 54, 12-25.

[13] Heywood, C.E. and Pope, J.P. (2009) Simulation of Groundwater Flow in the Coastal Plain Aquifer System of Virginia. U.S. Geological Survey Scientific Investigations Report 2009-5039.

[14] Powars, D.S. and Bruce, T.S. (1999) The Effects of the Chesapeake Bay Impact Crater on the Geological Framework and Correlation of Hydrogeologic Units of the Lower York-James Peninsula. U.S. Geological Survey Professional Paper 1612.

[15] Powars, D.S. and Bruce, T.S. (1999) The Effects of the Chesapeake Bay Impact Crateron the Geological Framework and Correlation of Hydrogeologic Units of the Lower York-James Peninsula. U.S. Geological Survey Professional Paper 1612.

[16] Holdahl, S.R. and Morrison, N.L. (1974) Regional Investigations of Vertical Crustal Movements in the U.S., Using Precise Relevelings and Mareograph Data. Tectonophysics, 23, 373-390. https://doi.org/10.1016/0040-1951(74)90073-0

[17] Snay, R.A. and Soler, T. (2008) Continuously Operating Reference Station (CORS)- 
History, Applications, and Future Enhancements. Journal of Surveying Engineering, 134, 95-104.

[18] National Geodetic Survey (2013) IGS08 Geodetic CORS Positional Antennae Reference Point (ARP) [GRS80 Ellipsoid] Computed Velocities. National Oceanic and Atmospheric Administration.

[19] Zervas, C. (2009) Sea Level Variations of the United States, 1854-2006. National Oceanic and Atmospheric Administration Technical Report NOS CO-OPS 053.

[20] Sallenger, A.H., Doran, K.S. and Howd, P.A. (2012) Hotspot of Accelerated Sea-Level Rise on the Atlantic Coast of North America. Nature Climate Change, 2, 884-888. https://doi.org/10.1038/nclimate1597

[21] Bindoff, N.L., et al. (2007) Observations-Oceanic Climate Change and Sea Level. Chapter 5 of Climate Change-The Physical Science Basis. Contribution of Working Group I to the Fourth Assessment Report of the Intergovernmental Panel on Climate Change, Cambridge University Press, New York, 385-432.

[22] Church, J.A., Clark, P.U., Cazenave, A., Gregory, J.M., Jevrejeva, S., Levermann, A., Merrifield, M.A., Milne, G.A., Nerem, R.S., Nunn, P.D., Payne, A.J., Pfeffer, W.T., Stammer, D. and Unnikrishnan, A.S. (2013) Sea Level Change. In: Stocker, T.F., Qin, D., Plattner, G.-K., Tignor, M., Allen, S.K., Boschung, J., Nauels, A., Xia, Y., Bex, V. and Midgley, P.M., Eds., Climate Change 2013: The Physical Science Basis, Contribution of Working Group I to the Fifth Assessment Report of the Intergovernmental Panel on Climate Chang, Cambridge University Press, Cambridge and New York.

[23] Cronin, T.M. (2013) Sea-Level Rise and Chesapeake Bay. U.S. Geological Survey.

[24] Pope, J.P. and Burbey, T.J. (2004) Multiple-Aquifer Characterization from Single Borehole Extensometer Records. Ground Water, 42, 45-58. https://doi.org/10.1111/j.1745-6584.2004.tb02449.x

[25] Stocker, T.F., Qin, D., Plattner, G.-K., Tignor, M., Allen, S.K., Boschung, J., Nauels, A., Xia, Y., Bex, V. and Midgley, P.M. (2013) Climate Change: The Physical Science Basis. Cambridge University Press, Cambridge, United Kingdom and New York.

[26] Mace, R.E. (2011) Peer Review of Virginia's Groundwater Management Program. Virginia Department of Environmental Quality Final Report.

[27] Eggleston, J. and Pope, J. (2013) Land Subsidence and Relative Sea-Level Rise in the Southern Chesapeake Bay Region. Report No. 1392, US Geological Survey.

[28] Eggleston, J. and Pope, J. (2013) Land Subsidence and Relative Sea-Level Rise in the Southern Chesapeake Bay Region. U.S. Geological Survey Circular 1392.

[29] Galloway, D. and Riley, F.S. (1999) San Joaquin Valley: California Largest Human Alteration of the Earth's Surface. Land Subsidence in the United States, U.S. Geological Survey Circular, 1182, 23-34.

[30] Dokka, R.K. (2006) Modern-Day Tectonic Subsidence in Coastal Louisiana. Geology, 34, 281-284. https://doi.org/10.1130/G22264.1

[31] Higgins, S., Overeem, I., Tanaka, A. and Syvitski, J.P.M. (2013) Land Subsidence at Aquaculture Facilities in the Yellow River Delta, China. Geophysical Research Letters, 40, 3898-3902. https://doi.org/10.1002/grl.50758

[32] Hanebuth, T.J.J., Kudrass, H.R., Linstädter, J., Islam, B. and Zander, A.M. (2013) Rapid Coastal Subsidence in the Central Ganges-Brahmaputra Delta (Bangladesh) since the 17th Century Deduced From Submerged Saltproducing Kilns. Geology, 41, 987-990. https://doi.org/10.1130/G34646.1 
[33] Engelhart, S.E., Horton, B.P., Douglas, B.C., Peltier, W.R. and Törnqvist, T.E. (2009) Spatial Variability of Late Holocene and 20th Century Sea-Level Rise along the Atlantic Coast of the United States. Geology, 37, 1115-1118.

Submit or recommend next manuscript to SCIRP and we will provide best service for you:

Accepting pre-submission inquiries through Email, Facebook, LinkedIn, Twitter, etc. A wide selection of journals (inclusive of 9 subjects, more than 200 journals) Providing 24-hour high-quality service User-friendly online submission system Fair and swift peer-review system Efficient typesetting and proofreading procedure Display of the result of downloads and visits, as well as the number of cited articles Maximum dissemination of your research work

Submit your manuscript at: http://papersubmission.scirp.org/

Or contact gep@scirp.org 